\title{
溶存酸素の測定と 酸素移動速度の決定
}

田口 久 治

大阪大学工学部醱酵工学教室

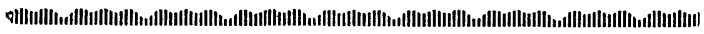

微生物の好気培養過程を有する発醭工業, 廃液処理に 拀いては，効率の良い通気攪汼をいかにして行らかの問 題の解決, また実験室の小容量でえられた結果を工場規 模の発酵タンクでも兄られるような通気・攪找条件を決 定するための検討が必要である．これには培養液に溶解 している酸素を測定し発酵過程における酸素需給を倹討 しなければならない.すなわち正確に培養系に溶解する 酸素の量および速度を測定することが肝要となる.酸素 の移動に関する問題が特に発酵の関与する分野で重要な のは, 酸素の溶解度が小さく，したがって培養系に拈け る他の栄養基質の移動と比較するとき，その濃度勾配が 小さいためである. 近い将来発酵工業のプロセスとして 採用されんとしている連続培養の管理面に和いても, 当 然溶存酸素濃度の制御が重要となってくるであろう。ま た使用する発酵タンクのある操作条件下に和ける最大酸 素吸収速度は，しばしばタンタ構造の相違による通気効 率の比較に用いられている。このように発酵系に打沙る 酸素の挙動を解析することは，管理，スケールアップの 両面からその重要性が指摘されてきた。しか子その目的 によって, 実に数多くの溶存酸素濃度の測定法と, 通気 効率を決定するための酸素吸収速度 (O.A.R.) または総 括容量係数 $\left(K_{L} \cdot a\right)$ の求め方について報告されてきてい る. 特に後者の $K_{L} \cdot a$ の決定法については, 化学工学 の分野で総括酸素移動係数 $\left(K_{L}\right)$ と気・液接触面積 $(a)$ をそれぞれ別々に分けて決定できる段階にまで進展して いる. しかし発酵工業においては従来酸素供給側からの 研究に主眼が抢かれ，微生物の対酸素挙動を中心とした 研究ならびにスケールアップの例はきわめて少ない，発 酵過程に打汀る溶存酸素は菌の発育相の変化に従って推 移するものであり, 菌の呼吸, 酸素の吸収速度も発酵進 展に伴う物理的性状の変化によって激じく変動するので, この解明を一層複雑なものとしているのであるが，これ
らの基礎的研究の開発が必須の段階となっている.この ように培養系の酸素濃度を測定し通気効率を決定するこ とはきわめて重要なことであり, 発酵の種類および研究, 解析の目的によって数多くの測定法が発表されている. 本邦においても山田 ${ }^{(1)}$, 田辺 ${ }^{(2)}$, 大橋 ${ }^{(3)}$, 砂原 ${ }^{(4)}$, 矢野 ${ }^{(5)}$, 合葉 ${ }^{(6)}$ らによって測定法ならびに $K_{L} \cdot a$ の決定法につ いてすぐれた研究報告なり, 総説が発表されているので, 筆者がここに述べる内容は多くの点で重累する箅所も多 いが，最近に発表されている 2,3 の実験例をあげなが ら溶存酸素の測定と酸素移動速度の決定法について紹介

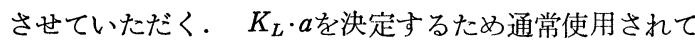
いるのは次の 4 つの方法である.

（1）触媒を使用した亜硫酸ソーダ溶液における酸素 吸収

（2） ポーラログラフ法の応用によって溶存酸素を測 定寸る gassing out 法

（3）同じく gassing out 法ではあるが化学的な方 法で溶存酸素を測定する方法

(4) Aerobacter aerogenes の上ら以酸素摄取速度 が速く, かつその発育速度が酸素供給と相関のある 微生物を使用する方法

その他最近，ポーラログラフ法と膜電極を組久合わせ るとか, テフロン膜の管を浸漬せしめて溶存酸素を測定 する方法, ならびにガスクロマトグラフを応用すること などが報告されている.

\section{1. 化学的方法}

この方法を気液接触の評価に使用したのは Cooper, Ferstorom, Miller ${ }^{(7)} ら か ゙$ 最初で, その後広く利用されて きた．特に発酵タンクの通気効率を比較するにはきわめ て便利な方法である．原理は $\mathrm{Cu}^{++}$または $\mathrm{Co}^{++}$の存在 下で $\mathrm{SO}_{3}$ 塩を $\mathrm{SO}_{4}$ 塩に酸化する速度を測定するもので ある. 溶存酸素と $\mathrm{SO}_{3}{ }^{--}$の反応はきわめて迅速であり， したがってこの反応速度を支配するのは液中への酸素の 溶解と考号られる. しかもこの反応は $\mathrm{SO}_{3}^{--}$の広い濃 度範囲で影響されることがない。この酸化反応はヨード 法で滴定される。なお本法の変法として, Corman ${ }^{\left({ }^{8}\right)}$ は dry ice を滴定中に使用し $\mathrm{SO}_{3}$ 塩の酸化進行を防止し， Ecker と Lockhart ${ }^{(9)}$ は $\mathrm{Na}_{2} \mathrm{~S}_{2} \mathrm{O}_{3}$ による逆滴定に和け るョードの決定に比色法を用いて改良している. 本法は 広く採用されているが，単にその条件下に沶いて発酵夕 ンクに供給されらる酸素の最大溶解速度を与えているだ けであって, 実際の微生物培養下汇拈ける酸素利用速度 に対して適確な知見を与兄るものではない，従来本法に 
よって決定された酸素吸収速度係数 $k_{d}$ は, 培養の過程 に拉ける総括物質移動係数を测定しているのではなく， 模型的な発酵タンクに拈ける総括物質移動係数を測定し ているにすぎず，培養過程に抢ける初発 $\mathrm{pH}$ を決定して いるようなものであり, 通気条件が一定であっても発酵 の進行とともに変化する培養液の物理的諸性質の変化は 考慮されていない. 物理的な要因が亜硫酸ソーダ法によ る測定結果を支配することについては Finn(10), Abel(11) らが討論している.

しかし酵母の培養系において, Gaden(12) らによって 報告されているごとく, 発酵タンクの通気排気に関する 物質収支と本法により求めた移動速度とがきわめてよく 適合しているという例もあり，決して見捨てることので きない方法である. また Lumb らはA.aerogenes の発 育と西硫酸ソーダ法におけ子酸化速度とは広い範囲で相 関があると述べており，Johnson(13) によって第 1 表の ごとくその関係がまとめられている.

\section{第 1 表}

\begin{tabular}{|c|c|c|c|}
\hline 微 生 物 & $\begin{array}{c}\text { 最大呼吸速度 } \\
\left(\mathrm{mMO}_{2} / l / \mathrm{min}\right)\end{array}$ & $\begin{array}{c}\mathrm{Na}_{2} \mathrm{SO}_{3} \text { 法に } \\
\text { るる吸収速度 } \\
\left(\mathrm{mMO}_{2} / l / \mathrm{min}\right)\end{array}$ & 研 究 者 \\
\hline Seratıa & 9.7 & 100 & Smith ${ }^{(14)}$ \\
\hline Aerobacter & 065 & 04 & $\operatorname{P}_{1 r t}{ }^{(15)}$ \\
\hline Aerobacter & 135 & 142 & P1rt ${ }^{(15)}$ \\
\hline Azotobacter & 035 & 027 & $\begin{array}{l}\text { Owen, John- } \\
\operatorname{son}^{(16)}\end{array}$ \\
\hline Saccharomyces & 025 & 0.20 & $\begin{array}{l}\text { Maxon, John- } \\
\text { son }^{(17)}\end{array}$ \\
\hline Saccharomyces & 232 & 2.28 & " (17) \\
\hline Saccharomyces & 5.7 & 6.0 & (17) \\
\hline
\end{tabular}

以上の結果から, 覀硫酸ソーダ法は発酵液への酸素移 動に関する最大速度を与えていることとなる. 対象とな る微生物が細菌, 酵母でしかもその濃度が異常に高くな い場合には, 覀硫酸ソーダ法によって測定された酸素移 動速度で比較検討することが可能である.すなわち流動 関係とか消費動力の挙動もまったく一致する場合には, 本法で求められた $K_{L} \cdot a$ 值を用いてスケールアップの 基準にすることができる.これらの実験例については Bartholomew ${ }^{(18)}$ らによる詳しい総説がある.

化学法としては Winkler 法も溶存酸素測定に広く使 用されている. 本法の欠点は, 多量の試料と特殊な分析 装置, ならびに長時間を要することであるが, その連続 測定法が廃液中の溶存酸素測定に用いられている例もあ る. その後 Loomis ${ }^{(19)}$ は indigo carmen 色素溶液が 黄色から青色に変化する酸化を利用して，培養濾液につ いての測定が可能なことを報告している．しかし実際の 培厓系に扫ける溶存酸素を正確迅速に測定するためには，
後述するポーラログラフ法などを利用しなければならな いのは当然である.

\section{2. ポーラログラフ法}

Baumberger ${ }^{(20)}$ によって最初に利用されて以来 Sker. mann, Millis ${ }^{(21)}$ によって詳細に記述され, 亜硫酸ソ 一ダ法とつねに比較され普遍的に使用されてきたのがポ 一ラログラフ法で, 加圧して測定した電解電流に相当す る溶存酸素量を求めるものである. 本法は培養系の溶存 酸素濃度が直接測定できるため高く評価されてきた．初 期の使用法は主として sampling 法であり，できる限り 迅速な測定を培養液について行なったり, 一度窒素カス で gassing out した後に再び通気を行なって溶存酸素. ならびに吸収速度を測定する方法が採用されていた。す なわち通笑を一応遮断して測定するとか，薬剂添加によ って微生物の呼吸活性を低下せしめて測定する方法が採. 用されていた，薬剤添加によって呼吸を阻止する方法は その実際例が Bartholomew ${ }^{(22)}$ によって示されており， シアン化物, フェノール，硫酸などを用いることができ るが, シアン化物は低い $\mathrm{pH}$ では使用困難であり，フ ェノール，硫酸にしても呼吸活性を完全阻止するには少 なくとも 10 秒以上を要するので, 呼吸活性の強い場合 通気を止めた状態で溶存酸素を数秒で消費し尽与培養液 に対して薬剂を使用する価值はほとんどない。したがっ て, 溶存酸素を正確に測定するには発酵タンク系外に sampling 乙ては意味がなく，系内に電極を值接插入す るのが有利である．電極插入については，回転電極を用 いた Chain, Gualandi ${ }^{(23)}$ ，照井 ${ }^{(24)}$ ，滴下水銀電極を用 いた Bartholomew，大橋らの報告がある。しかし回転 白金電極は直接挿入に際して培養液中の有機物質による 污染が激しく，長期の連続使用が困難であるし，水銀滴 下電極は機械的覺拌によって影響を受けやすく，実際の 発酵タンクには使用が困難である．前者については最近 膜電極が，後者に対しては陽極に Agのアマルガムでで きた円盤を用いて $\mathrm{Hg}$ の遅い速度の供給をらけ，が 連続的に電極が回転ベルベット円盤でみがかれるように した改良法が報告されている．膜電極については，試料 液中に存在する種々の物質には無関係に溶存している分 子状酸素のみを選択的に測定するために Kamienski ${ }^{(25)}$ が微小 Pt 電極の表面を hydrophilic colloid の吸着 フィルムで被覆したものを，ポーラログラフ法に適用し

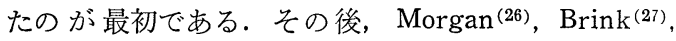

Drenckhahn ${ }^{(28)}$ らが血中酸素の測定にシリコンフィル ム, 寒天, コロジオンフィルムでそれそれ電極を被覆 


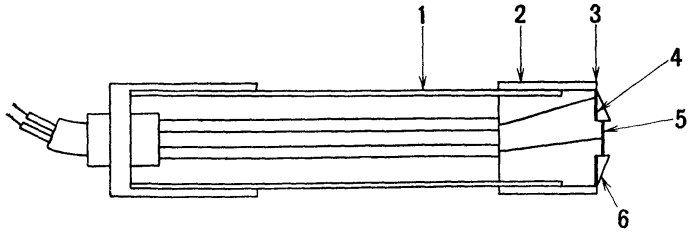

第1図 膜電極の一種 MPE 102 (砂原, 中島)

1. プラスチック製チューブ

2. プラスチック製キャップ

3. $\mathrm{Ag}-\mathrm{Ag}_{2} \mathrm{O}$ の対極

4. $025 \mathrm{M} \mathrm{KOH}$ の電解液

5. $\mathrm{Pt}$ 陰極

6. $0.025 \mathrm{~mm}$ のポリエチ レン膜

し, さらにClark ${ }^{(29)}$ は, セロファン透析膜, コンドー ムゴム, ポリエチレン膜を比較試験して, ポリエチレン 膜が通気性透過膜として最もすぐれていることを報告 している. また, 海洋学の関係では, Carrit, Kanwisher ${ }^{(30)}$ がポリエチレン膜の電極を用いている. 発䣼の分 野では, Gualandi, Ugolini, Chain(31) がセロファンま たはコロジオンで Hg のアマルガム電極を被覆して振蕰 フラスコ中の溶存酸素を測定している. これらの多くの 研究を経て最近害用に耐兄るものが製作されてきており， Phillips, Johnson ${ }^{(32)}$ らによって発醉タンクに抢ける繁 気殺菌にも耐兄るテフロン膜の使用が適していることが 示された. 結局現在使用されているものはテフロンとポ リエチレンであり，熱関係のない場合にはポリエチレン 膜で充分である、ポーラログラフ法を組み合わせる場合 には, 電極の陰極はほとんぞが $\mathrm{Pt}$ か $\mathrm{Au} て ゙$, 対極は $\mathrm{Ag}-\mathrm{AgCl}, \mathrm{Ag}-\mathrm{Ag}_{2} \mathrm{O}$ 電極であり, 内部電解液として は $\mathrm{NaCl}, \mathrm{KCl}, \mathrm{KOH}$ 溶液などが用いられている. 陰極 は主として円板状で，陽極は輪状に製作されたものが多 く, 砂原らは第 1 図のごとき産業廃水中の溶存酸素測定 用の $3 \mathrm{~mm}$ 径の $\mathrm{Pt}$ 円板陰極と輪状 $\mathrm{Ag}-\mathrm{Ag}_{2} \mathrm{O}$ の対極 とを用いている. 高分子膜は通常 $0.025 \sim 0.05 \mathrm{~mm}$, テ フロン膜では $0.02 \sim 0.05 \mathrm{~mm}$ 程度のものが適当とされ ている. 膜と陰極表面はできる限り接近していることが 必要で，先端が平面でなく球面に作製されたものもある. 大橋(33) は陰極面を適当な圧力で膜に押しつけることに より, 膜 - 電極間の電解液量を調節し良好な結果をえて いる.膜電極は温度の変化に対して影響を受けやすく, 膜の種類によっても異なるが，約 2 10\%/deg の範 囲で電流值が変動するといわれ, Meyling, Frank ${ }^{(34)}$, Carrit ${ }^{(35)}$ らによってサーミスターを内部に付設して温 度補償を行ならような電極も示されている。

次に電解質の濃度も問題となる。たとえば陰極に $\mathrm{Ag}$ を使い電解質として $\mathrm{KCl}$ を用いる場合， $\mathrm{Cl}^{-}+\mathrm{Ag} \longrightarrow$ $\mathrm{AgCl}+\mathrm{e}^{-}$の反応によって $\mathrm{Ag}$.が消費される. $\mathrm{Cl}^{-}$が
なくなってくると, $\mathrm{Ag}+\mathrm{OH}^{-} \longrightarrow \mathrm{AgOH}+\mathrm{e}^{-}$の反応が 起こり, $\mathrm{AgOH}$ は電極面に付着せずに膜面に集積して 感度を低下せしめる原因となる。また高い $\mathrm{Cl}^{-}$濃度で は $\mathrm{AgCl}$ は複合イオンを作って著しい電気メッキの状 態が起こるので好ましくないとされており, 最適 $\mathrm{Cl}^{-}$ 濃度は 0.5 0.7 M であることが示されている.

膜電極に抢ける酸素移動の原理について, Finn ${ }^{(36)}$ は その標準曲線が濃度の变化した塩溶液中の飽和酸素濃度 と拡散電流值との間で決められる通常のポーラログラフ 法の場合と同様に決定できないことを示し，膜電極の場 合は酸素濃度を測定しているのでなく，むしろ酸素活性 を測定しているのだと結論している。これは Strohm， Dale ${ }^{(37)}$ らによっても確認された。すなわち濃度の異な る食塩および庶糖溶液中に空気を飽和し，その溶存酸素 を水銀滴下電極とポリエチンン膜電極とを用いて測定し た結果, 水銀滴下電極では電流値と溶存酸素の間に直線 の相関がえられるのに反し, 膜電極では変化が見られな い.しかし空気と窒素の混合比を変えて通気すると, 膜 電極においても電流值は溶存酸素濃度に比例した。

膜電極に和忷る酸素移動の機構について Strohm む 次の考察を行なっている.すなわち, 酸素は空気中から 水溶液中へ，そしてポリエチレン膜を通して最後は白金 電極表面て酸素濃度が零となる。したがって，単位時間 に電極の単位面積当りに供給させる酸素モル数を $N$ と し, 膜に打ける拡散係数を $D$, 膜之溶液接触面に和ける 酸素飽和濃度を $C_{s}$, 膜の厚さを $d$ で示すと,

$$
N=D\left(-\frac{\partial C}{\partial d}\right)=D\left(\frac{C_{s}-0}{d}\right)
$$

空気と水溶液の間で酸素が移行するには濃度勾配が耐 相の間になければならない.しかしこの場合は膜の抵抗 が大きく, 気・液間の濃度変化は無視できることになる. このような環境下に和いては周囲の空気と液中のガス分 圧は平衡になり，膜表面は液内の分圧と平衡であるので， 膜表面は結局空気中の酸素分圧と平衡になり，液は単に 酸素移動の媒体として存在するの及で, 液中に和汀る酸 素の溶解性は重要でなくなり, 膜電極でえられる測定值 は分任または溶存酸素の活性を測定していることになる. 細胞膜は明らかに高い拡散抵抗をもち，電極の膜と同様 の挙動をしていると考兄ると，培養系に执いては，実際 の溶存酸素濃度よりも膜電極で測定された酸素活性の値 の方が意義があるとも述べている．膜電極の応答速度は 研究者によって相違しているが, 通常 1 分以内て Beckman Model 777 では $90 \%$ の応答が 20 秒といわれてお り，砂原らによると MPE 102 型では溶存酸素量が小か 
ら大に増加するときは約 5 秒，その逆の場合は約 30 秒 ぐらいを要すると報告されている.膜電極感度の維持性 は数時間の単位で再現性が認められ，大橋によると 48 時間以上安定していることが示されている． pH の影響 は, Strohm が糖蜜で行なった実験によると， pH 5.0 以下では酸素分圧と拡散電流が正確な比例関係を有して いるが，pH が 6.0 になると低い酸素濃度範囲で直線関 係がくずれている． $\mathrm{SO}_{2}$ などの低分子の揮発性酸を含む ような場合についてはさらに問題点が残っている。また 膜表面に打ける試料溶液の流速は測定值に大きな影響を もち, Beckman Model 777 で $3.5 \mathrm{ft} / \mathrm{sec}$. 以上の流速 下で安定して拈り，Carrit らによると $0.2 \mathrm{~cm} / \mathrm{sec}$. 以 上で一定值を与えることが示されている，矢野らは，電 流值はジャーファーメンターで覺拌を行なわないとさに は攪拌を行なったときの 50〜70\% で不安定であり， 粘度 $28 \mathrm{cp}$ の培地で 250 r.p.m. 以上の㩭拌速度を与え て初めて安定であったと報告している. 新しい電極を使 らときは電極の種類によってはかなりの準備期間を必要 とし, 電解液が少量のときで $5 \sim 10$ 分, 多量のときは 8 〜9時間を必要とするといわれる．これは電解質に溶解 している酸素を還元するに要する時間である. 筆者も $\mathrm{Pt}$ を陰極とし電解液に $\mathrm{KCl}$ 溶液を用いたポーラログラフ 法との併用に和いて，安定化に約 5 時間を要した.

なおポーラログラフ法の応用として, Blakebrough, Hamer ${ }^{(38)}$ らは発醉液中の酸素移動に対する抵抗の研究 で溶存酸素の分布に対する攪拌の影響を決定するに際し， 最初酸素が飽和するまで通気を行ない, 規定の攪拌速度 に調整すると同時に $\mathrm{N}_{2}$ ガスを送り， $\mathrm{N}_{2}$ による溶存酸 素除去の速度を測定している．この方法に打いても実際 にはポーラログラフ法で酸素濃度を測定しているのであ るが，酸素の気泡は拡散電流曲線を描く上に障害となる に反し， $\mathrm{N}_{2}$ 気泡はほとんど影響しないことに本法の利 点があると述べている. $4.5 l$ のジャーファーメンター

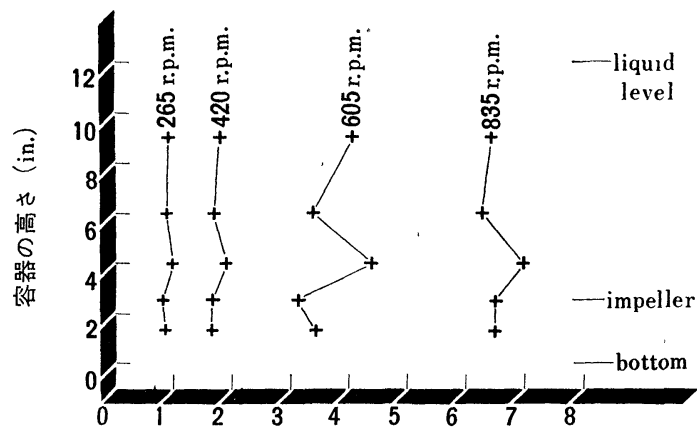

$\mathrm{N}_{2}$ 拡散速度係数

第 2 図 ジャーファーメンター壁における溶存酸素分布
で 5 本の電極を用い, 各部分の $\mathrm{N}_{2}$ ガス拡散速度により 溶存酸素分布を求めた例は, 第 2 図のごとくである.す なわちこのジャーファーメンターでは 605 r. p.m. 以上 の攪拌速度で翼の下部にも気泡を充分分散せしめらるこ とを示している。また，Phillips ${ }^{(39)}$ らはPt電極と $\mathrm{Ag}$ $-\mathrm{AgCl}$ の半電池をオッシロスコープに連絬し，溶存酸 素分布の微視的な観察を行なった. 容量の大きな発酵夕 ンクで粘性の高い培着液となった場合，覺汼と溶存酸素 の分布に関する研究は微生物の発育，呼吸との関連性を 追求する上で重要な課題であり，上述の才法などによる， 検討が有効なものである.

\section{3. ガルバニ電池法応用の溶存酸素計}

ポーラログラフ法は外部より加電する方法であるが, ガルバ二電池方式の原理と隔膜電極を組み合わせたもの. で, 外部から加電する必要のない電極も最近用いられて いる.この方法の原理は指示電極と刘極を直接試料中に 浸漬して両極間に発生する電流を測定するもので, 最初; Tödt(40) らによって陰極に $A u$ ，陽極に $Z n$ を用いたも のが作られ, その後, 膜で両極を被覆する形にまで進展 した．電極の組合せとしては，Ag-Pb， Cu-Al， Al-C, $\mathrm{Al}-\mathrm{Pt}$ なぞがみられる. 第3図はこの1例で，Gore, Phillips ${ }^{(41)}$ によって示されたものである. 電解液とし て $\mathrm{KCl}$ 溶液の代りに $95 \%$ のエチレングリュールに $\mathrm{KCl}$ を飽和したものを使用すると沸点が $120^{\circ} \mathrm{C}$ 以上に なり, 特に発酵タンクのように殺菌されるものについて

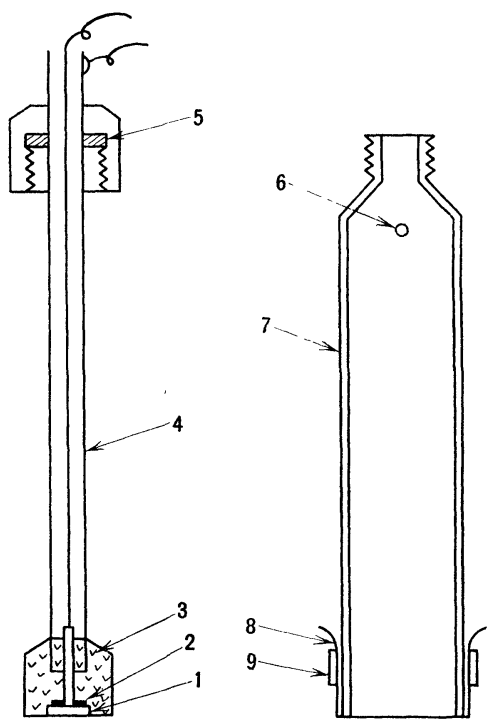

第 3 図 ガルバニ電池応用の溶存酸素計 (Gore, Phillips)
1. 白金電極
4. アルミニウム管
7 ガラス管
2. ゴム盤
5. ゴム盤
3. エポオキシ樹脂
6 ベント
8. テフロン膜
9 ゴム輪

(38)

化学と生物 


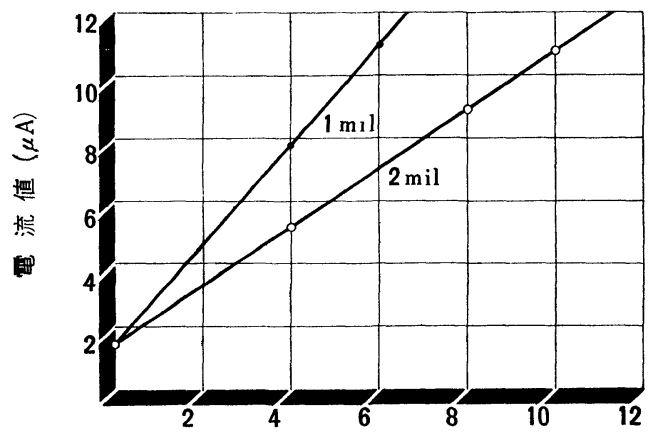

容存酸素濃度 (ppm)

第 4 図 還元電流値と溶存酸素との関係

は, 膜 - 陰極間の距離が、電解液の膨張などにより変化し て測定誤差を来たす現象を防ぐことができるといわれて いる. 第 4 図は, 筆者がこのガルバ二電池方式の電極に 1 mil 括よび 2 mil のテフロン膜を使用して， $1 \%$ グル コース溶液中で作製した標準曲線である.Mancy ${ }^{(42)} ら$ は, $\mathrm{Ag}-\mathrm{Pb}$ 系に $1 \mathrm{M} \mathrm{KOH}$ を電解液として使用し, 溶 存酸素 $1 \mathrm{ppm}$ 当りの発生電流值 $1.05 \mu \mathrm{A}$ をえている ので, ほとんど筆者らの結果と差はない.なお, 電流計 は0 15 $\mu \mathrm{A}$ の範围のものを用い, $0.1 \mathrm{ppm}$ まで検出 可能であった. カルバ二電池方式では, 特に電解液が陽 䟝を浸さないものでなければならず，内部抵抗の小さい 電流計で両極を短絡するのであるから，陰極で酸素の還 元が円滑に進行しなければならない条件が必要である.

最近 Lingane ${ }^{(43)}$ によると, Pt 極での酸素の還元は $\mathrm{Pt}$ -PtO 対を考元て説明しているし, Pt よりも $\mathrm{Ag}$ 電極 の万が安定であることを示している. このガルバ二電池 方式の電極には, 振動電流を除去するために大容量のコ ンデンサーを含んだ安定回路を使用すると便利である.

外部電源を必要としないガルバ二電池方式の隔膜電極 法は, 実用的な見地から現在最も便利な方法である.

\section{4. 物理的な方法}

Phillips, Johnson は発醉タンク中にテフロン膜で作 られた管を插入し，テフロン膜から浸透してくる溶存酸 素を管中を一定速度で流通する $\mathrm{N}_{2}$ ガスで追出し，この 混合ガスを Beckman oxygen analyzer に送入して酸 素を分析する，いわゆる“Tubing method”を発表し， 膜電極と同様良好な結果をえることを示した．彼らによ ると, $0.012^{\prime \prime}$ の厚さで $1 / 8^{\prime \prime}$ 径のテフロン管を $40 \mathrm{ft}$ タ ンク中に送入し， $30^{\circ} \mathrm{C}$ の水に空気を飽和せしめた状態 の溶存酸素を測定したとき, $20 \mathrm{~m} l / \mathrm{min}$. の流速で $\mathrm{N}_{2}$ ガ スを流通せしめると $0.3 \%$ の酸素含有量となり, oxygen analyzer の感度にさらに適応せしめるには長さを
$100 \mathrm{ft}$ に延長し $40 \mathrm{~m} l / \mathrm{min}$. の $\mathrm{N}_{2}$ 流速にすればよい結 果をえるであろうと推察している。 また Humphrey. ${ }^{(44)}$ はこの tubing method を応用して第 5 図のごときテフ ロン膜でできた箱型の検出器を発表し，ガルバニ電池で ある $\mathrm{Pb}-\mathrm{Ag}$, 電解液 $\mathrm{KOH}$ 溶液系と電流計を組み合わ せて, ジャーファーメンター中の溶存酸素測定が可能な ことを示している．連続発酵における測定とか高精度の 值を望を場合には，発酵タンク中への付設方法さ兄適確 にすれば蒸気殺菌による影響が少なく，検量曲線が安定 しから半永久的に使用でき，広範囲の箇所の溶存酸素の 平均值をえる点で, 将来膜電極法よりも tubing method の改良型が開発されてくるものと考光られる. 他方, 通気量を決定するためにBungay ${ }^{(45)}$ が純物理的な方法を 採用している.すなわち発酵タンク中の水分が通気され た空気によって運び去られる量で通気速度を決定するも のである. 飽和空気は $32^{\circ} \mathrm{C} て ゙ ~ 0.0335 \mathrm{~g}$ の水を含有し ており, $60 \%$ の相対湿度を有する空気は $0.021 \mathrm{~g}$ の水 分しか含んでいないので, $1 l$ の空気は $0.0134 \mathrm{~g}$ の水 を蒸発したときには約 $151 \mathrm{~m} / \mathrm{min}$. の空気流速であるこ とが判明する.また振盪フラスコ中に煙草の煙を充媜し ておいて，栓を開放すると同時に煙がまったくなくなる までの時間を測定して通気の程度を決定する方法も示さ れている.これらの方法はまったく一次的な通気の知見
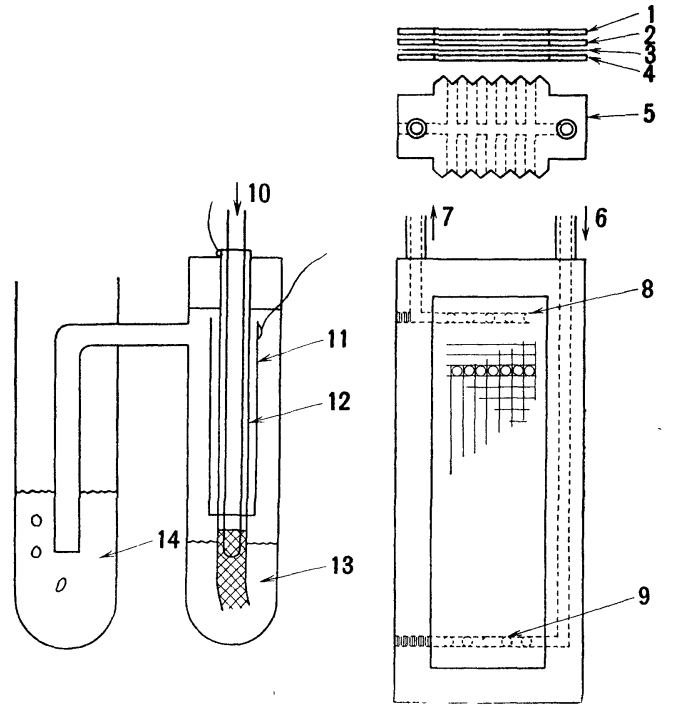

第 5 図 Humphrey 設計のテフロン膜箱型溶存酸素計

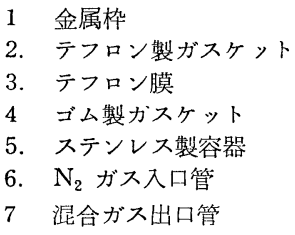

8 混合ガス出口孔

9. $\mathrm{N}_{2}$ ガス入口孔

10. 混合カス入口管

11 鉛管

12 銀製絧

13. $1 \mathrm{~N} \mathrm{KOH}$ 溶液

14 水 
を与えるにすぎないし，亜硫酸ソーダ法とも良い相関を 示さなかったといわれている.

\section{5. 磁気式酸素分析計}

酸素特有の磁気的性質を利用した分析計で, 多成分ガ ス中の酸素を高精度で分析できるといら特徵から燃焼か ス中の酸素分析に使用されていた。たと光ば酸素の相対 磁化率は $\mathrm{O}_{2}:+100.00, \mathrm{~N}_{2}:-0.36, \mathrm{CO}_{2}:-0.63$, $\mathrm{Ar}:-0.58, \mathrm{CH}_{4}:-0.37$ のごとく非常に特異な常磁 性を有している. Hay's Magno-Therm Analyzer は熱 線式のものであるが，その他酸素の磁気性の久を利用す る Beckman $\mathrm{F}_{2}, \mathrm{G}_{3}$ type むある. 本装置は発酵タンク の場合には通気入口, 出口に付設して流通空気中の酸素 含有量を測定し, 酸素供給速度, 利用速度の測定に利用 できる。また，微生物の呼吸の比較的無視できる河川と か廃液中の溶存酸素の連続測定に， $\mathrm{N}_{2}$ ガスをキャリヤ 一ガスとして使用し，第6図に示すごとき prototype のアスピレーターを回路に有する連続溶存酸素脱離機を Hay's の磁気分析計汇連結する試みを Levine ${ }^{(46)}$ らが

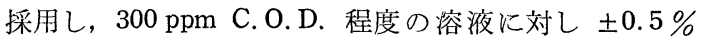
の精度で測定が可能なことを示している. 本邦において も, 水素中に溶存酸素を抽出し, この $\mathrm{H}_{2}, \mathrm{O}_{2}$ の混合ガ スと電解水素との熱伝導率の差を熱伝導型検出器により 測定する酸素計など，多くの種類の溶存酸素計が試作さ

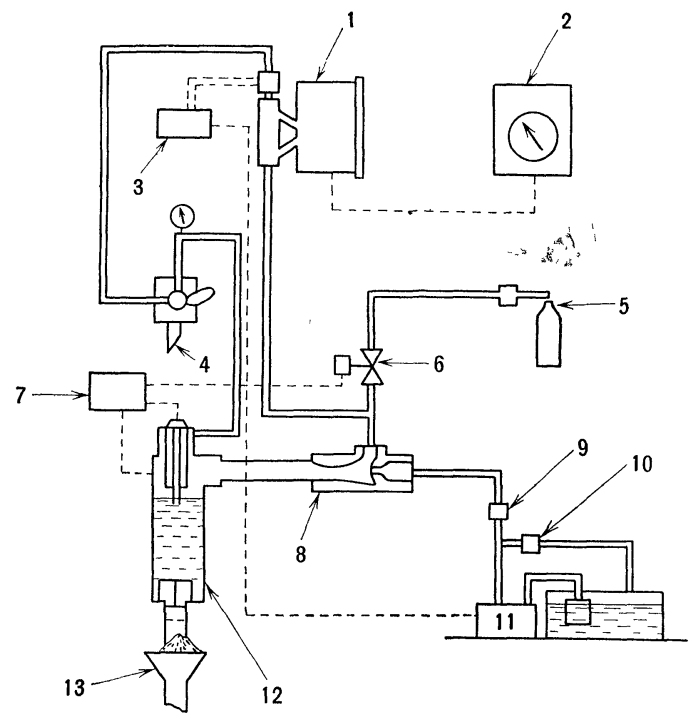

\section{第 6 図 Hay's の連続溶存酸素測定回路}
1. 酸素分析計
6. 電磁分
10.リリーフ升
2. 記録計
7. リレー
3. リレー
8. アスピレーター
11. ポソプ
4. 空気
9. 压力調整装置
12. 気液分離装置
5. $\mathrm{N}_{2}$ ガス

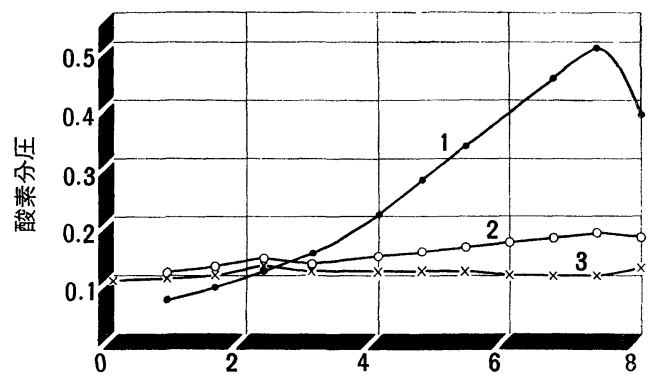

時 間

第 7 図 酵母培養系における溶存酸素制御の一例

1 酸素摂取 $\times 10 \quad 2$ 送入酸素 3 . 溶存酸素

れている。

これら磁気式酸素分析計と膜電極を同時にジャーフォ ーメンターの内外に付設し，溶存酸素濃度の自動制御を 行った報告が，Siegell, Gaden ${ }^{(12)}$ にっっされている.

この際制御方式としてガス中の酸素分圧を変更すること に基礎を和く方法を採用し，通気速度は一定のまま酸素 と窒素の組成を変更しうる特殊なバルブによって混合か スを供給する，希望する酸素隼位を維持するための自動 調節バルブは溶存酸素電極之調節計に連結されており， ガスの入口，出口を走査する酸素分析計は酸素吸収およ び酸素摂取速度を決定しうるための知見を与えることが できるようになっている．酵母の培缸についてえられた 結果の 1 例は第 7 図のごとくである。また培養経過中の 溶存酸素变化の標準プログラムを作成しておき，これに 追従するように攪拌機の速度を変更せしめて酸素吸収速 度を変更する方法が Ping(47) によって報告されている。 これらの溶存酸素制御の方式はこのままの形で工場に応 用することは困難であっても，将来工場操作に和ける溶 存酸素制御の基礎となるべきデーターをえるためには必 須の方式と考光られる。

\section{6. ガスクロマトグラフ法の適用}

1958 年に Bethune ${ }^{(48)}$ がビール中の空気を測定する のに用いたのが最初で，その後医学分野で Ramsey ${ }^{(49)}$ が血漿中の溶存ガスの測定に応用し，本邦では若杉(50) らが同じく血液中の溶存酸素の測定に用いている．その 後河川, 海水中の水質検查のために溶存ガスを測定する のに, Swinnerton ${ }^{(51)}$, Williams ${ }^{(52)}$ らがガスクロマト グラフを採用している.この方法については当研究室の 吉川(53) らが基礎的研究を行なって拉り, 発酵液に対し ては筆者らの研究とほぼ同時期に Roxburgh ${ }^{(54)}$ が溶存 ガスの測定を行なっている．ガスクロマトグラフ法は操 作が簡単で再現性があり, 溶存酸素だけでなく, 同時に 


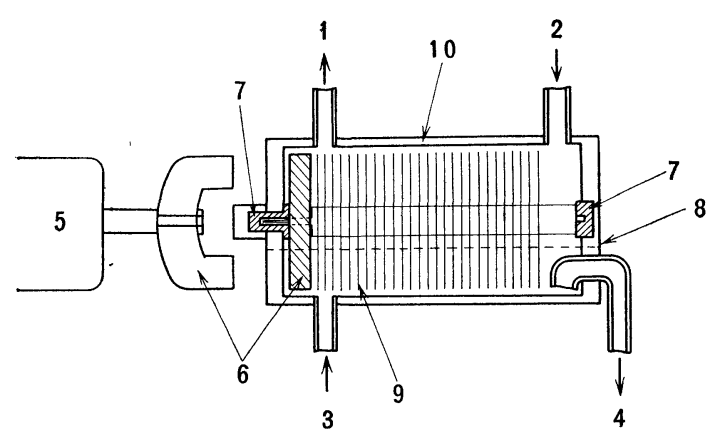

第 8 図 Swinnertonの連続溶存ガス抽出装置
1. $\mathrm{He}$ 出口
2. $\mathrm{He}$ 入口
3. 試料液入口
4. 廃液出口
5. モーター
6. 磁石
7. テフロソ製ベアリング
8. 最適水準
9. 回転円板
10. 外枠

他のガス $\left(\mathrm{CO}_{2}, \mathrm{~N}_{2}\right.$ など） も測定できる利点がある. ただ溶存ガスの測定には, 磁気式酸素分析計と同じく溶 存ガスを液から適当なキャリヤーガスで抽出して分析に 供さなければならぬ欠骝があり, 微生物系の培養液の場 合には試料をタンク外に移さねばならぬことが最大の欠 点である. しかし第 8 図に示したWilliams の multiple spinning disk のごとく, 短期間に連続的に溶存ガスを 抽出しらる装置なども考案されているので, 適当な連続 抽出装置さえ調達できれば本法の使用も可能と考えられ る. 現在筆者らは, ガラス製 $10 \mathrm{ml}$ 程度の三角フラス コで内部にガラスフィルターを熔着し, 注入した試料を 電磁攪拌によって振盪しながら下部から送入されるキャ リヤーガスで試料中の溶存ガスを追い出す型を使用して いる．本法において次に注意すべき点は，カラムを通過 する試料ガスの脱水を充分に行なうべき点であり，単な る吸収剤, 乾燥剤, たと㓪ばポリエチレングライュール， グリセリンなどのみの使用では充分でなく, 冷却法をシ リカダルカラムと併用して良い結果をえることができる。

Swinnerton らは水中の $\mathrm{CO}_{2}, \mathrm{O}_{2}, \mathrm{~N}_{2}, \mathrm{CH}_{4}, \mathrm{CO}$ 同時に分析し, Williams は $\mathrm{N}_{2}, \mathrm{O}_{2}, \mathrm{CO}_{2}$ を, また Roxburgh と吉川は発酵液中の $\mathrm{CO}_{2}, \mathrm{O}_{2}, \mathrm{~N}_{2}$ を分析してお り, カラムの充垍剤は Molecular Sieve が主体で, シ リカダルのカラムを $\mathrm{CO}_{2}$ 分析用に併設した型が多い. 検出部はサーミスター方式のものが最も有利であり, キ ヤリヤーガスは $\mathrm{He}$ または $\mathrm{H}_{2}$ でその流速は 50〜90 $\mathrm{m} l / \mathrm{min}$. が最適である. 試料は $1 \sim 2 \mathrm{ml}$ を使用して溶 存酸素 $0.1 \mathrm{ppm}$ の範囲まで測定することができる.

\section{7. 微生物利用による酸素吸収速度の測定}

発酵タンクのスケールアップに Aerobacter aerogenes
の発育変化を用いらることが, Lumb, Mercer, Wilkin(55) らによって示された.すなわち菌自身の発育を制 限しない培地で，A，aerogenes を培養すると細胞への 酸素供給速度は発育速度を調整する因子となることが示 されている．2つの容量の異なった発酵タンクで A. ae rogenes の等しい発育速度をえたとすれば，両タンクの $K_{L} \cdot a$ は等しいといえる．また A. aerogenes の発育速 度は亜硫酸ソーダ法で測定された $K_{L} \cdot a$ ときわめて良 い相関を有していることが示されて和り，したがって A. aerogenes を使用してタンクの $K_{L} \cdot a$ を測定するこ とも可能である. Tsao, Kempe ${ }^{(56)}$ は Pseudomonas ovalis NRRL-B-8 株がブドウ糖を定量的にグルコン酸 に転換し, 消費される酸素がグルコン酸の生産に関連し ていることを利用して酸素移動速度を決定しているす なわらグルコン酸の生成速度を観察することによって酸 素移動速度が決定できる. 彼らは $5 l$ のジャーファーメ ンター中に前培養された P.ovalis の菌体を $1.76 \times 10^{10}$ $\mathrm{cell} / \mathrm{m} l$ の濃度になるよう $2 l$ の培地 (グルュース $50 \mathrm{~g}$, $\left.\mathrm{KH}_{2} \mathrm{PO}_{4} 1.2 \mathrm{~g}\right)$ に接種し, 稼働条件を変更してグルコ ン酸生成を測定し, $K_{L} \cdot a=0.2 P_{v}^{0.8} G^{0.2} E^{-0.5}$ moles $\mathrm{O}_{2} / l \cdot \mathrm{hr}$ なる相関をえている. 合葉 ${ }^{(57)}$ らもグルコン酸発 酵を利用して，菌周辺の酸素移動に関する抵抗について 詳細な報告をしている。

発酵タンクにおける酸素移動の追跡にこれら微生物の 発育を対象にして $K_{L} \cdot a$ を決定する方法は非常に意義 の深いものであり, 特にしばしば粘性の激しく変動し非 ニュートン体流動を呈するカビ, 放線菌に属する菌株で, この測定に適合する性質を有するものが見いだされれば 非常に有利となる.

\section{8. 結 論}

上述した以外にも気相中の酸素測定などに打いて数多 くのものが最近報告されているし，それぞれの方法によ って求められた $K_{L} \cdot a$ 值の比較なども示されているが, 要するに $K_{L} \cdot a$ と目的生産物収率との相嘱がある場合 の発酵タンクのスケールアップのために酸素移動速度を 決定するには，一貫して同一の方法を採用して $K_{L} \cdot a$ の検討をすれば良い訳であり，発酵タンクの管理のため に溶存酸素を測定するには，現在のところ熱殺菌に耐え る酸素透過性テフロン膜容器をタンク内に設置し酸素計 を系外に設置する方法が最上と考える、殺菌を妿しない 場合とか, 微生物の分布が少ない廃液, 河川に和ける溶 存酸素の連続測定には, ガスクロマトグラフ法が便利で ある.

(たぐち・ひさはる) 
文献

（1）山田浩一，高橋撉二：酸協誌，10，338 (1952)；12, 158(1954)

（2）田辺 修, 島田昌司: 同 上, 14,68(1956).

(3) 大橋 実, 成本恒夫：工化, 6,893(1957)

(4) 砂原広志, 中賉良三: 化学分析, 12,411(1963)

(5) 矢野俊正, 中原忠筍, 山田浩一：䣫協誌, 21, 110(1963)。

(6) 合葉修一: 続新化学工学講侳, “酸酵工学” (1960)

(7) P D Cooper, G A Ferstrom, S A. Miller : Ind Eng Chem, 36, 504(1944)

(8) J Corman, H M Tsuchiya et al : Appl Microbiol., 5, 313(1957)

(9) R E Ecker, W R Lockhart : ^bıd, 7, 102(1959).

(10) R K.Finn : Bacteriol Rev , 18, 254(1954)

(11) F Abel : Mh Chem, 82, 815(1951).

(12) S D Siegell, E L Gaden : Biotechn and Bioeng, 4, 345 (1962)

(13) M J Johnson : Recent Progress in Microbio., p. 397 (1958)

(14) C G.Smith : Ph D thesis, University of Wisconsin (1954)

(15) S J Pirt: J Gen Microbiol., 16, 59(1957)

(16) S P Owen, J J Johnson: Agric and Food Chem, 3, 606(1955)

(17) W D Maxon, M J Johnson: Ind Eng Chem, 45, 2554 (1953)

(18) W. H Bartholomew : Advance in Appl Microbiol , 2. 289(1960)

(19) W F Loomis : Anal.Chem., 28, 1347(1956)

(20) J P Baumberger : Cold Spring Harbor Symposia Quant Biology, 7, 195(1939)

(21) V B Skermann, N Millis : Aust J. Exp Biol. Med. Sct , 27, 183(1949)

(22) W.H Bartholomew et al : Ind Eng.Chem., 42, 1810 (1950)

(23) E B Chain, G Gualandi : $R C$ Ist Sup Santt, 17, 17 (1954)

（24）昭井堯造，金野筋之：醱酝誌，37，529(1959)。

(25) B Kamienski : Bull Acad Polon Scı:, 5 (6A), 85(1949).

(26) E H Morgan, G G Nahas: Federation Proc, 9, 91 (1950)

(27) F Brink: "Methods in Medical Research", Vol. 2 (1950)

(28) F O Drenckhahn : Naturwtssensc haften, 38, 455(1951)

(29) L.C Clark et a1.: J Appl Physiol , 6, 189(1953);

Trans Am. Soc Artif. Int Organs, 2, 41(1956).

(30) D E Carrit, J W Kanwisher: Anal Chem, 31, 5 (1959)

(31) G Gualandi et al : Abstracts (22L) (7th Inter. Cong Micro Stockholm, 1958).

(32) D H Phillips, M J Johnson : J Biochem Micro. Tech. and Eng , 3, 261 (1961).

(33) 大橋 実: 第 5 回生物化学工学研究会, 昭 37 年 6 月, 東大応微研

(34) A.H Meyling, G H Frank: Analyst, 37, 634(1962)

(35) D E Carrit, W J Kanwisher : Anal Chem, 31, 5 (1959)

(36) R K. Finn : Proc 136 th Meeting, Am Chem Soc. Atlantic City (1959)

(37) J A Strohm, R F Dale : Ind Eng Chem, 53,761(1961)

(38) N Blakebrough, G Hamer:Biotechn and Bioeng. 5, 59(1963)

(39) D H Phillips, M J Johnson:J Bıochem Micro Techn. Eng , 3, 277(1961)

(40) F Todt, H. G Tödt: Arch Metall , 1, 469(1947)

(41) 生物化学工学講習会, 昭 38 年 6 月, 東大応微研.

(42) K H Mancy et al : J Electroanal Chem, 4, 65(1962).

(43) J J Lingane : ıbıd , 2, 296(1961)

(44) A E Humphrey : 生物化学工学講習会, 昭38年 6 月, 東大応 微研

(45) H.R Bungay et al : J.Biochem Micro Techn Eng 2, 143(1960)

(46) H S Levine et al : Anal Chem, 28, 343(1956)

(47) Shu Ping: Ind.Eng Chem., 48, 2204(1956)

(48) J L Bethune et a1 : J. Inst. Brew , 64, 100(1958)

(49) L.H Ramsey : Scrence, 129, 900(1959).

（50）若杉文吉, 大熊佳晴 : 化学の領域, 增刊 44,205(1961).

(51) J W.Swinnerton et al : Anal Chem., 34, 483(1962)

(52) D D Williams et a1 : ıbıd, 34, 657(1962)

（53）吉川光一, 田口久治, 寺本四郎 : 瞪工誌, 印刷中 (1964)

(54) J M Roxburgh : Can J. Microbio.,' 8, 221(1962).

(55) M Lumb et al : Abstracts (24 h) (7 th Inter Cong Microbiol Stockholm).

(56) G T. Tsao, L L Kempe: J. Biochem Micro Techn Eng , 2, 129(1960).

（57）合葉修一, 原 正幸, 染谷潤一郎 : 醱工誌., 41, 74(1963)

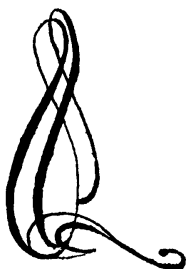

News:

フグ毒テトロドトキシン

津 田恭介

フグにはたくさんの種類があり，なかには鑑別の難し いものもあるようである．阿部宗明氏の近著に「原色魚 類検索図鑑」という，素人にもわかり良い魚類学の本が あるが，これに日本近海に見られるフクが洩れなく収載 されている. 合計で 35 種，内訳はハコフグ亜目ハコフ グ科 6 種, マフグ亜目のマフグ科 27 種, およびハリセ ンボン科 2 種である. マフグ科のものが大体有毒で, 卵 巣, 肝臓, 腸などの臓器に有毒成分が濃厚で, 肉や血液 にはない、フグの種類や季節により，あるいはまた同じ 種類でも個体差があるからいちがいにはいえないが，臟 器だけは敬遠した方が良い。数年前に, 遠洋漁業によっ て冷凍して持ち帰ったフグの肉で相当数の中毒者を出し， うち5名が死亡した事件が北九州市で起ったが，これは ドクサバフグによるものであった、ベトナム，ボルネオ， フィリピン近海のドクサバフグには筋肉にも毒成分のあ ることがこの事件で確認された。

中毒死が多いため, 明治時代には一時禁止条例も出さ れたフグ料理も，時代の進歩に伴い食品衛生の面での取 締り, たとえば卵巣などの臟器は魚市場から出される前 に拔き廃棄する等の措置がとられ，最近では北九州や関 門地方はおろか日本全国に普及し，冬になるといたると ころフグ料理の看板が見られるようになった。 このよう にフグの需要は增したが, 肝心のフグそのものは, 高級 品のトラフグの魚獲が減る一方，したがってマフグ（ナ メラフグ）やショウサイフグ（ナゴヤフグ）など值段が トラフグの $1 / 10$ か $1 / 50$ の安いフグが主として食べら れている。

フグの中毒症状は食後早ければ 30 分, 遅くも 3 時間 以内に起り，軽い中毒は悪心や口唇のしびれなどで終る. 中毒が進むと手指, 前膊などの知覚鈍麻ついで運動麻痺 が現われる.ついで全身運動麻痺，骨格筋の弛緩，声も 出なくなる，呼吸麻㽻が来て死亡するが，要するにフグ 毒テトロドトキシンは強い神経毒である，治療法として は，現在のところ中毒があまり進まないらちに，人口呼 吸をして排泄をまつしかない，排泄は比較的早いようで ある. 結晶テトロドトキシンの毒力はマウス $1 \mathrm{~kg}$ 当り 10 マイクログラム（腹腔注, 皮下注) で, フグ以外の 動物は中毒し，その致死量も似たりよったりである. 径 口的の場合その毒力は前記致死量の $50 \sim 100$ 倍と思克 ばよい。

フグの放卵期は 5 月下旬頃で，東京湾付近のクサフグ 